HStud 26 (2012)2, 273-283

DOI: 10.1556/HStud.26.2012.2.7

\title{
A MAN FOR ALL SEASONS: EXILE, SUFFERING AND MARTYRDOM IN THE AUTOBIOGRAPHY OF MIKLÓS BETHLEN*
}

\author{
ZSOMBOR TÓTH \\ Institute for Literary Studies, Research Centre for the Humanities, \\ Hungarian Academy of Sciences \\ Budapest, Hungary
}

\begin{abstract}
This paper attempts to evaluate the historical anthropological process of self-fashioning performed by count Miklós Bethlen. In doing so, the aim of my interpretation is to delineate those cultural and historical contexts that influenced Bethlen's habit of constituting and fashioning a self in his ego-documents. Taking as a point of departure Bethlen's twofold liminality, I argue that he identified himself with the prototype of the early modern Calvinist martyr, so that he could provide an account of his life imitating the so called récit martyrologique as a narrative genre. Bethlen's self-fashioning displayed in his memoirs, letters and political projects, reveals his special commitment to Puritan theology and devotional culture as well.
\end{abstract}

Keywords: Chancellor of Transylvania, ego-documents, autobiography, self-fashioning, Puritanism, récite martyrologique, l'anthropologie Calvinienne

\section{Introduction}

The life and destiny of Count Miklós Bethlen (1642-1716), superbly depicted in his memoires, is a thrilling and captivating narrative about his afflictions, successes and tragedies, hence, it has been regarded as a valid and reliable testimony of the turbulent times he experienced. Moreover, his account mastered from the overlapping narratives of his private life and contemporary history, promoted him as an eyewitness and an outstanding historical personality of the epoch. It is this story of his life, which overtly qualified him as a subtle connoisseur and victim of the persons, institutions or events he recalled in his written account. Indeed, his relatively long life coincided with the major changes and the unavoidable decline of the Principality of Transylvania; a haunting series of unfortunate events, from the loss of independence to the Habsburg invasion and occupation. The tragic course of his life transformed his destiny, in the eyes of the contemporaries, in one

* This paper was written with the support of the Bolyai-scholarship (2012-15) offered by the Hungarian Academy of Sciences. 
of the most significant examples of misfortune; for it must have been quite a sensation to have seen the chancellor of Transylvania charged for high treason and sent to prison. Although initially sentenced to death, Bethlen was never executed, but kept in prison in Vienna until the end of his life. The allegedly most brilliant mind and statesman of Transylvania died on the 27th of October, 1716 in isolation and neglect. Not even a single portray envisaging him survived to posterity, though he mentioned in his autobiography that he had ordered a smaller and larger one from a painter, while in Vienna, in 1665.

However, in default of the missing effigies that might have preserved the face(s) of Bethlen, the literary historian can exclusively rely upon a number of texts, functioning as ego-documents, produced by the chancellor. Thus, there is this remarkable possibility to examine the process during which Bethlen represented himself, his personality, his spirituality, and eventually his face. Accordingly, the main preoccupation of this paper is to construe the process of constituting and fashioning a self in the ego-documents written by Bethlen during his imprisonment from 1704 to 1716 . My approach, as one committed to the methodological convictions of historical anthropology, claims that Bethlen wrote his autobiography and the other ego-documents in a special, twofold liminality, for his overall condition must have been determined by his imprisonment and his ageing. Therefore the habit of writing, the need to utilize literacy must certainly have been a reaction ensuing from his liminal status, both spiritual and physical. The aim of my interpretation is to sketch this historical anthropological process of self-fashioning, ${ }^{1}$ pointing out and surveying the cultural patterns and blueprints assimilated by the author in order to forge a credible identity in front of posterity. I will conclude by claiming that Bethlen's self-fashioning equally illustrates his intellectual excellence and the unrevealed significance of early modern Hungarian, Puritan-oriented literacy and devotional culture.

\section{Contexts and Antecedents}

In order to decipher the subtleties of Bethlen's discourse, we have to distinguish some relevant historical and cultural contexts which might have provided the historical anthropological frame of his oeuvre, and the ego-documents subject of this analysis. Indeed, a contextual explanation helps to disentangle the particular conundrums of his mental world and life course as well. For many of the events of utmost importance in Bethlen's life were inseparably related to the fate of the Principality. As a matter of fact, the distant observer may remark that all the significant changes and decisions, Bethlen opted for, were often derived from events, 
actions or happenings that would influence the existence of the little state. Bethlen was born in the "Fairyland" under the rule of Prince George I Rákóczi, but soon he was to learn the decline and final collapse of the Principality (1658-1662). Then, the Habsburg occupation and its aftermath ensued (1687-1690), during which he managed to obtain the Diploma Leopoldinum (1691) offering legal guaranties for the privileged nations (Hungarians, Szeklers, and Saxons) and confessional communities living in Transylvania. Towards the end of his life, he was to witness the plundering and ultimate peril of the Fairyland, during the rebellion lead by Francis II Rákóczi. Disappointed by this unfortunate turn of events, he made a last effort and proposed a political solution to the emperor, but the project (Columba Noe cum Ramo olivae..., Hagae, 1704) written for this purpose had been confiscated and transformed into the major evidence of his alleged intention of committing high treason. As innocent as he was, deserted by the coward and jealous fellow members of the gubernium, he was sentenced to death. Notwithstanding his repeated attempts to exculpate himself, he had never been officially pardoned or rehabilitated. One cannot omit the striking parallel; while Bethlen was born in the Principality referred to as the Fairyland, when he died in prison, the Fairyland also vanished, and just a ruined and extremely poor Habsburg province remained. Both of them disappeared far too easy, far too sudden.

Besides these woeful events, frequently recalled in oral and written accounts of the contemporaries, the heritage of the Fairyland represented cultural values, institutions and artefacts as well. The rulers of the semi-independent states embraced Reformation from the early beginnings, thus by the time Bethlen was born, and started his studies, a Calvinist, Puritan-oriented religious culture and educational system had been developing. Furthermore, Bethlen, having enjoyed all the privileges of those belonging to aristocracy, had been provided an outstanding education. Under the guidance of first, Pál Keresztúri, a supporter of Comenius's pedagogy, and then, János Csere Apáczai, a committed follower of Alsted's encyclopedism, he assimilated an up-to-date package of knowledge centred upon the Ramist dialectics and incorporated into the Puritan theological teaching of Ames and Perkins. Since Bethlen's father, an eminent literate man and statesman as well, insisted on his son's impeccable education, Bethlen was provided an impressive tour in Europe, a mixture between a Cavalier's Tour and Peregrinatio Academica. During the prolonged time he had spent in Europe, the young Bethlen not only assimilated new knowledge but also fulfilled some kind of political missions as well, consisting mostly in exchange of information and delivering letters.

All in all, Bethlen commenced his adulthood and public service soundly prepared with Puritan piety inculcated in his soul, and with an encyclopaedic knowledge assimilated and stored in his mind. Though he had intensely relied on this outstanding education during his political career, he did not manage to avoid the 
unfortunate and sad ending of his public service and life as well. Not even the unofficial title of being the most learned man of his age saved him from imprisonment.

\section{Bethlen's Account as Self-Fashioning}

Due to this aforementioned overview comprising some relevant historical and cultural contexts framing up Bethlen's life as a sequence of historically relevant events, it is possible to delineate the most influential cultural antecedents that brought about the creation of the ego-documents narrating the chancellor's life story. These ego-documents undertook the twofold function of informing the contemporaries and the posterity, first, about the afflictions, tragedies and revolting injustices suffered by Bethlen, and then, to have exemplified his deep, personal and spiritual commitment to both Ecclesia and Patria, that is, the Calvinist Church and the Principality of Transylvania. Thus, Bethlen not only provided his contemporary and future readership with his own version of his flagrant case, but also managed to perform a multifaceted and complex identity, casting himself as a victim, in fact, as a martyr. All those ego-documents both Latin and Hungarian, representing several genres, conveyed one major role, that of a martyr of both church and fatherland.

Bethlen's self-fashioning circumscribed a great variety of texts displaying this major role of a martyr, which clearly stemmed from his liminal status. His prevalent preoccupation to evaluate or to decipher the hidden meanings of his liminoid status and identity followed the behavioural patterns of those in exile. The imprisonment he suffered, much alike to the living conditions of an émigré, may have well recreated the experience of political exile. Bethlen's discourse bears the mark of those typical features which qualify it as one belonging to early modern culture of migration. ${ }^{2}$ Furthermore, this liminality and its textual representations linked to the experience of exile, persecution and suffering reveal Bethlen's special concern to imitate an influential and highly esteemed cultural pattern of contemporary Calvinism. For Bethlen may have considered that only the identity pattern of the Calvinist martyr would beseem his role. In order to incorporate it in the narrative(s) about his life, from poetical, theological and political considerations, he decided to imitate the narrative structure of the so called récit martyrologique. It is this special type of narrative genre that was primarily assigned in early modern Calvinism to promote the life story of martyrs, so much different from the Catholic saints of the Middle Ages. Bethlen's choice to acquaint his future readers with the detailed story of his life relying on the récit martyrologique was motivated in a suggestive manner:

...the persecution of the world upon me has been extraordinary from my youth up, and in particular my twofold bitter imprisonment... ${ }^{3}$ 


\section{1. The Quintessence of Bethlen's Self-Fashioining: Via Salutis}

Reiterating the findings that Bethlen's procedure of constituting a self, implied the incorporation of two major components - I have referred to the prototype of the martyr and the récit martyrologique as a narrative genre - of contemporary Calvinist devotional culture, one can rightly impel for further revealing investigations, concerning the historical anthropological explanation of self-fashioning acts. For it is almost certain that Bethlen aforementioned choices were not incidental at all. Due to his excellent Puritan theological education, he assimilated the Calvinist teaching of double predestination and via salutis. The concept of the via salutis or gratiae gradus also favoured by the Puritan divines, including Perkins and Ames, envisaged human existence as a process, strikingly resembling the anthropological concept of rite de passage during which the elect individual performed a ritual journey of his existence. Ames, the Puritan theologian, conceived this process as consisting of predestination, vocation, justification, adoption, sanctification and glorification. This phenomenon during which the elect individual discovering its election could improve his person and character, in fact, it is a certain rite de passage because is focused upon the last lifecycle event, death, and afterlife. This particular vision of human existence had been originated from Calvin's theology promoted by Puritanism and later on defined as Calvinian anthropology (l'anthropologie calvinienne). ${ }^{4}$ Bethlen also shared this view:

\footnotetext{
...you [God], before the creation of the world, had unconditionally elected me in our Lord Jesus Christ, first for holly, unblemished life and then for eternal life. ... You cleansed me from all my sins with the blood of your beloved Son in baptism, then adopted me and made me one belonging to your house. ${ }^{5}$
}

Consequently, Bethlen's narration followed this pattern as a script, confirming the thesis that God's elect people would endure suffering and afflictions for they gained eternal life. Thus, persecutions, injustices and afflictions became the ultimate proof of martyrdom, patiently undertaken by those very few, the chosen ones. Bethlen's access to Calvinist martyrdom - besides the Puritan classics, Ames and Perkins, he had certainly read - was granted by Hungarian Puritans as well. István Nagy Szőnyi (1632-1709), he himself a victim of religious persecution during the 1670s, not only assimilated Calvinist theology and martyrology, but he wrote the very first Hungarian marytrological book, inspired partially from his own experiences. The book published in 1675, may have well entered Bethlen's library. Moreover, taking into account the fact that Szőnyi as a refugee came from the Hungarian Kingdom and undertook service in Transylvania in different locations, Bethlen must have met him. For Bethlen followed closely the destiny and the case of the persecuted Calvinist and Lutheran priest; he wrote a 
Latin letter to all the priests sent to the galley, as a gesture of his solidarity with their noble cause and to focus the attention of the other Protestant states on the events taking place in the Hungarian Kingdom. ${ }^{6}$

All in all, Szőnyi's definition of martyrdom is unmistakably echoed by Bethlen's self-fashioning, for it is very clear that they shared the same convictions. Szőnyi claimed:

\section{All those who are patiently suffering their afflictions are martyrs. ${ }^{7}$}

This motif of the patient suffering, frequently recurring in Bethlen's discourse, was meant to ease his liminality and point out his very special condition and status. Accordingly, Bethlen seemed to intimately follow Szőnyi's argumentation about Calvinist martyrdom, for when he equated his imprisonment with martyrdom suffered for the church and fatherland, he might have relied on Szőnyi's view, who asserted:

Martyrs are those persons, who witnessed the Justice, suffered prison or any kind of affliction, even though they were not killed. ${ }^{8}$

It is possible to surmise that Bethlen's attempts to provide posterity with an account of his life were designed with the declared aim to construct an identity accommodated to the Puritan theological teaching of via salutis and the Calvinist patterns of martyrological tradition. Bethlen's conviction of his being a martyr was directly ensuing from his creed of being elect, homo electus. He often claimed that religious despair, desperatio never overwhelmed him, for his belief in salvation and eternal life would always prevail.

\section{2. Applications}

Having surveyed some of the most influential theological, devotional and poetical contexts that had certainly articulated Bethlen's narratives, it became clear the nurturing influence of Calvinism and Puritanism. Moreover, Bethlen's theological and devotional choices were of paramount importance, since they carved purposefully the representations of his personality, life and deeds. The Calvinist concept of the martyr's prototype, often referred to as saint too, but with no relation whatsoever to medieval hagiography, provided Bethlen with the optimal frame for poignantly describing himself and the relevant events of his life. He seems to have chosen deliberately it, despite the rancorous contemporaries discrediting attempts, which did not bother him too much: 
Let us speak briefly of the saints. What harm has the world's wicked judgement, persecution and condemnation ever done the saints...

It is this particular intangibility of the saints or martyrs, for they usually act, write and speak to a sympathetic posterity that may have motivated Bethlen to bring forth his story, prove his innocence, and unmask the injustices committed against him relying on the récit martyrologique as the optimal narrative genre for exhibiting his martyrdom. This rationale explains the writing up of the very first narrative about his life in Latin: Sudores et Cruces Nicolai Comitis Bethlen (1704). The prevailing motif of being persecuted, maliciously charged and unjustly sentenced did not only explain away his extremely difficult situation but it was equally part of his self-fashioning. It seems to me that, as early as 1704 , Bethlen had already created a basic design for a self that was to be further articulated and fashioned. While his claim that all his life he served only God, his earthly rulers and his own conscience and did not intend to harm anyone, ${ }^{10}$ may have sounded in 1704 as a standard confession of the politician kept under arrest; this formulation of loyalty toward the Calvinist church and Transylvania, his fatherland, would become the main argument of his martyrdom after 1708. Indeed, one can sense that the second and third narratives of his life, strongly interrelated and both written in Hungarian, The Prayer Book of Miklós Bethlen ${ }^{11}$ and The Autobiography of Miklós Bethlen, between 1708 and 1710, not only targeted a different readership, but augmented the importances of his persecutions and sufferings as an expression of his martyrdom. The two texts written consecutively display such coherence that I shall treat them as one narrative. Bethlen decided to put on the story of his life profiting of the advantages of a récite martyrologique, thus he suggested that a Latin translation published together with the Hungarian version would be for the benefit of the Calvinist Church.

However, the light ambiguities of the Latin narrative were eliminated in the Hungarian version, which unmistakably imposed Bethlen's character as a martyr. In addition to this, the whole narrative seemed to be organized in such a way as to exhibit the intimate and personal history of Bethlen's martyrdom. For instance, there is an intelligently figured up and permanently sustained balance between the account of the events with almost historical accuracy, and their personal interpretation provided by Bethlen himself. This biased intertwining of personal history with real historical events occurring in Bethlen's time, the chancellor was often eyewitness to some of the happenings, produced a strange effect. The fictitious and clearly biased narrative of the imprisoned count was so powerful and authoritative that it was taken by contemporaries as real history. That is to say, Bethlen's sincerity as a poetical device inventively incorporated into the genre and narrative potential of the récit martirologique gave such a convincing authority to his fiction, as if it were a totally objective and unbiased account of historical events. This 
is how Bethlen's martyrdom, we have to admit, though fabricated from his subjective impressions, experiences and interpretations, was conveyed to historical reality.

Thus, the liminality of imprisonment vanished, and the torturing and senseless waste of life had spectacularly been replaced by a sacrifice undertaken for the sake of both Ecclesia and Patria. Bethlen, the martyr, developed the strong creed that his patient suffering is a penitence to temper God's anger and soften his sentences. The prisoner may have lost all his earthly power and high offices he used to hold, still, he gained the most important position; he became the martyr of the church and the fatherland:

...for I do believe, dear God, that it was for my benefit to be kept here in this grievous prison so that I could cry and mourn for all the sins committed by my nation and my house; in order to soften your sentence by prayer, lent and penitence. ${ }^{12}$

Bethlen's self-fashioning centred upon the idea that the imprisonment was his act of martyrdom, after 1710 prevailed in his other ego-documents as well. No doubt that his advancing in aging also contributed to the urge of a final, great and ethically immaculate identity pattern to be assimilated. Still, it is remarkable how this twofold liminality influenced his communication with his family members as well. When he heard about his daughter, Julia's sadness and crying because of Bethlen's long imprisonment, he comforted her, rather surprisingly, in a letter dated to 1712 . There is a remarkable passage, which reads like this:

My beloved daughter, I have heard that you lament a lot because of me. Do not cry for me, but instead thank God for allowing your father to suffer for His glory and the benefit of our fatherland. For my affliction is the infallible mark of His blessing cast on you. ${ }^{13}$

In a similar way, a letter dated to 1715 recalls the same self-fashioning. Bethlen had instructed his wife about some tasks he wanted to be executed, and then, made a very special reference to his imprisonment.

\section{...I approach crying my grave, but not because of my imprisonment,} for that is my crown. ${ }^{14}$

Bethlen's assertion that his imprisonment was a crown, he probably proudly worn, points to a very special connotation. Apart from biblical textual antecedents, this particular motif of the crown constituted a direct link to the Hungarian Calvinist martyrology. We have already seen that Szőnyi, as the very first martyrologist, had a remarkable influence upon Bethlen's mental world and self-fashioning in particular. The image to which reference was made in Bethlen's letter, 
is, in fact, the ritual act of identifying one's martyr status, for he who worn this crown of the martyrs, was certainly one of them. Therefore, this letter wrote shortly before Bethlen's death, was the last expression of his martyr status and identity. Moreover, Bethlen's gesture as a remarkable act of self-fashioning imitated the praxis of the Calvinist priests of his age, who often were attributing the crown of martyrs to their older colleagues, when they wrote congratulatory poems saluting and honouring their persons, careers or newly published books. For instance, when János Zilahi the senior published his Igaz vallásnak világos tüköre [Plain Mirror of True Religion], in 1672 at Kolozsvár, seven of his fellow priests wrote congratulatory poems to the book. One of the recurrent motifs of these short texts was the crown of the martyrs that Zilahi would justly expect for his lifetime achievements as a persecuted priest. Thus, Bethlen's usage of the crown motif as a reference qualifying imprisonment as martyrdom was not incidental at all. For Zilahi's book, just like Szőnyi's book might have been within his reach as he, a committed Calvinist and patriot, was eagerly observing and collecting all kinds of knowledge related to refugees and their martyrdom. All in all, this also testifies for the fact that Bethlen's deliberate imitation of an extant early modern practice of honouring recalling the motif of the crown, was due to his extensive knowledge of Hungarian martyrological literature.

It is possible to conclude that Bethlen's preoccupation to come to terms with his twofold liminality corroborated with his attempts of proving his innocence, brought about the emergence of a spectacular self-fashioning. The imprisoned chancellor, allegedly the brightest mind of his age, with an unusually sound education was good enough a writer to produce several texts in various genres, and have them as ego-documents promoting his self-definition as a martyr. The very first text, written in Latin, was just the opening act of a carefully designed and diligently constructed process of self-fashioning. The second long narrative, written in Hungarian, reflects Bethlen's preoccupation to cover newer segments of a possible readership and augment the fictitious history of his martyrdom. The last phase of his self-fashioning shows Bethlen's inventiveness of constructing a self at its perfection, but also testifies for a total assimilation of martyrdom as primary identity pattern.

\section{Conclusion}

The conclusion is, perhaps, unavoidable that Bethlen's self-fashioning is the ultimate proof of his intellectual and spiritual excellence. For this contextual explanation revealed those impressive areas of knowledge he had assimilated, and then, incorporated in his self-representations. Furthermore, the variety and richness of texts superbly written were often promoted as ego-documents so that they would 
display this unique and outstanding process of self-fashioning. Having evaluated Bethlen's case of self-fashioning, which implied the partial reconstruction of his mental world, or at least, a plausible version of it, the question still remains open: was the example of an extraordinary men's extraordinary life, fragmentally preserved in several texts, good enough to claim that self-fashioning may have been a standard cultural practice of early modern Hungarian literacy? Probably not, for Bethlen's oeuvre was an exception, exceeding the standard production of texts in every possible respect. Still, it does constitute a powerful example pointing to the unexplored significance of Hungarian Puritan-oriented literacy and devotional culture.

\section{Notes}

1 I am relying on Stephen Greenblatt's term, who grasps the process of self-fashioning in the following way:

"... it describes the practice of parents and teachers; it is linked to manners or demeanour, particularly that of elite; it may suggest hypocrisy or deception, an adherence to mere outward ceremony; it suggests representation of one's nature or intention in speech or actions (...) it invariably crosses the boundaries between the creations of literary characters, the shaping of one's own identity." Greenblatt, Stephen (1980) Renaissance Self-fashioning from More to Shakespeare (Chicago-London: The University of Chicago Press) 3. Greenblatt's concept was applied often to describe the process of shaping a religious identity in early modern Protestantism, especially in Puritanism.

Protestant Identities. Religion, Society, Self-Fashioning in Post-Reformation England (1999) eds. Muriel McClendon, Joseph Ward and Michael MacDonald (Stanford: Stanford University Press); Margo Todd (1992) 'Puritan Self-fashioning: The Diary of Samuel Ward' Journal of British Studies, July, 236-64; John Martin (1997) 'Inventing Sincerity, Refashioning Prudence: The Discovery of the Individual in Renaissance Europe' American Historical Review, December, 1309-42.

2 Smout, Christopher (1995) 'The Culture of Migration' History Workshop Journal, Vol. 40 (Autumn), 108-17.

3 The Autobiography of Miklós Bethlen (2004) transl. Bernard Adams (London-New York-Bahrain: Kegan Paul) 19.

4 El Kenz, David (1997) Les Bücher du Roi. La Culture Protestant des Martyrs (1523-1572) (Champ Vallon: Seyssel) 11.

5 Kemény János és Bethlen Miklós müvei (The Works of János Kemény and Miklós Bethlen) Ed. Éva V. Windisch (Budapest: Szépirodalmi Könyvkiadó, 1980), 985.

6 The letter was published in the Netherlands: Epistola Nicolai Bethlen Sedis Siculicalis Udvarhely, Capitanei Supremi, ad Ministros Exules tam Helveticae quam Augustanae Confessionis, Ex Hungaria per hodiernam persecutionem ejectos (Ultrajecti: 1677).

7 Szőnyi, István Nagy (1675) Mártírok Coronája... (The Crown of the Martyrs) (Debrecen), 5.

8 Op. cit., 6.

9 The Autobiography... (2004), op. cit., 17.

10 Kemény ... (1980), op. cit., 1183. 
11 Much to my surprise, Bernard Adam when translating Bethlen's autobiography, ignored the Prayerbook, despite the fact that it also contained an account of Bethlen's life, and it had preceded the writing of the autobiography. The Prayerbook constituted the most important textual antecedent of the autobiography for it displayed a great number of intertextual and cultural links illustrating the interrelatedness of the two texts. For the Prayerbook's significance in shaping Bethlen's mental world see. Tóth, Zsombor (2011) A koronatanú: Bethlen Miklós (The memoirs of Count Miklós Bethlen and the 17th century Hungarian and English puritanism) 2nd edition (Debrecen: Kossuth Lajos University Press), 35-40.

12 Op. cit., 997

13 Bethlen Miklós levelei (The Letters of Miklós Bethlen) (1987) Ed. József Jankovics, transl. Péter Kulcsár (Budapest: Akadémiai Kiadó), 1066.

14 Bethlen ... (1987), op. cit., 1122. 